\title{
A Study to Examine Teachers' Classroom Time Management Strategies At Secondary School Level
}

\author{
KIFAYAT KHAN \\ Department of Education, University of Haripur \\ kifayatkhan@uoh.edu.pk \\ DR. TEHSIN TAHIR \\ Department of Education, University of Haripur \\ Dr.tehseen78@gmail.com \\ DR. UMBREEN ISHFAQ \\ Department of Education, University of Haripur \\ umbreenishfaq@hotmail.com \\ ASAD KHAN \\ MPhil Research Scholar, University of Haripur \\ asadadamzai@yahoo.com
}

\begin{abstract}
Effective classroom management strategies can play an important role in teaching learning process. Classroom management encompasses many factors including management of subject matter, environment, discipline and time. These all are the byproducts of teacher's effective classroom management strategies. This study was focused to investigate the teacher's Classroom Time Management Strategies (CTMS) at secondary school level. All secondary school teachers of Khyber Pukhtunkhwah (KP) were considered as the population of the study. A sample of 480 teachers form 80 schools of five (5) districts $(96$ teachers to each district) was randomly selected. The sample was further distributed into eight (8) strata of male/female, urban/rural, science/arts, and public/private through stratified random sampling techniques such that the number of teachers in each stratum remains 240. The data was collected through a self-prepared questionnaire of reliability 0.87 and was analyzed through statistical tools. The analyzed data reflected that mostly teachers (62.7\%) were in practice to utilize time management strategies. Further it was found that: male teachers were superior to female teachers; urban teachers were superior to the rural school teachers; science teachers were superior to the arts teachers; and public school teachers were superior to the private school teachers in classroom time management strategies CTMS; and. Classroom management oriented refresher courses for female teachers may be arranged to abridge gender gap in various CTMS and these strategies should be stressed more frequently in curriculum and pre-service teacher trainings.
\end{abstract}

Keywords: investigation, classroom management strategies, time management, secondary level, refresher courses, 


\section{Introduction}

Time is realized as indefinitely dividable and utilizable goods in this modern age. The concept of time is infuses in all the organizations. Effective and smooth operation of an organization is only possible due the effective utilization of $4 \mathrm{M}$ resources including materials, men, money, and minutes (time). Time is the only resource that cannot be stored or bought. According to Macan, Shahani, Dipboye and Phillips (2000), the mystery of attaining success in life is the result of effective time management. Everybody have this resource equally and giving plenty significance to plan it. The competitive setting we live in today inspires individuals to organize and manage time effectually. To Alay and Koçak (2003), the high achievements of the organizations compel the managers to utilize time efficiently and issues orders to control it. Teacher's time management strategies have a strong correlation with the academic performance of the students. Time management according to Adamson, Covic and Lincoln (2004); Liu et al(2009)is strongly correlated to academic achievement. Further, time management techniques not only influence achievement but also helpful in multipurpose task completion (Fazal, 2012). Before going to discuss time management strategies, awareness regarding classroom management terminology is immense importance.

\subsection{Classroom}

A classroom is a room where activities relating teaching-learning may occur. Class is an assembly of learners organized together to receive shared instruction (Afridi, 2000). Both the learners and instructor are influenced by classroom learning environs (Emmer et al, 2000). The main purpose of the classroom is to provide a safe place for nonstop instruction without any interruption by disturbances.

\subsection{Management}

Management according to Samson and Daft (2003) is to accomplish the proposed aims through the joint struggles of the personnel. To Challam (2003), management is the procedure of dealing with or monitoring individuals or things. It is the effective use of material, time, money resources (Shahid, 2005). It is a social process planned to confirm: teamwork, contribution, and participation of individuals in the achievement of the established goals (Afridi, 2000).In conclusion, management is the procedure in which the director may modify the behavior of his/her staffs to attain the organization objectives.

\subsection{Classroom Management}

Classroom management is the art of arranging the classroom (Afridi, 2000). It is the activity aimed to minimize discipline related problems. It is the act of managing relations, performances, instructional situations, and sessions for groups of pupils(Iverson, 2003).Further, Santrock (2004) opines that classroom management laid further emphasis on guiding learners to become less depend on outer agent and more appropriate at self-will. In addition, Arends (2007) put stresses on the preventive aspect of classroom management. He asserts that preventive management is the viewpoint that much of classroom related complications might be resolved by means of good planning, exciting and related lessons, and useful coaching. In additions, classroom management mainly depends upon three (3)elements including important subject-matter, classroom-organization and effective instructional strategies(Larrivee, 2005; Charles \& Senter, 2002).

Evertson, Emmer, and Worsham (2003), Successful classroom management enhances chances of the learners. Lastly, Froyen and Iverson (1999); Khan, Khan and 
Majoka (2011) have present a complete notion about classroom management encompassing in the term of time-management. This paper put emphasis on the time management strategies.

\subsection{Time Management}

Every single occurrence is depends upon time and each event accomplished effectively is measured from the total utilized time. To Ugwulashi (2013), time management can guide towards useful and efficient learning development in the demanding period of economic fate. Theoretically, it is a number of habits or learnable actions which can be learned via improved knowledge, tutoring or deliberate exercise (MacCann, Fogarty \& Roberts, 2012). It represents a variety of techniques, skills, and tools utilized to manage time when achieving definite jobs, assignments and objectives (Davis, 2000; Strongman \& Burt, 2000; Sabelis, 2001; Raymond, 2008). In addition, time management behavior is at attaining an efficient usage of time during the accomplishment of certain goal-directed tasks (Claessens, Van Eerde, Rutte \& Roe, 2007). Using time so wisely that the objectives of classroom management are attained is known as time management. Majority of instructors undergo worries because they have numerous activities to perform in a small amount of time. Consequently, the instructor frazzled due to overload of difficult tasks. All of these anxieties, frustrations can be overcome if the instructor manage his time effectively. As a result of good time management skills the instructors may plot and accomplish their responsibilities efficiently and can achieve their required aims (Parkay\& Hass, 2000; Freiberg \& Driscoll, 2000).

\subsection{Time Management Strategies}

Several researchers and authors have discussed time management skills in their projects (Allen, 2001; Morgenstern, 2004; Forster, 2006; Fiore, 2006; Raymond, 2008). These strategies of time management are very supportive for entrepreneurs and instructors to be more effective in time management in order to accomplish the anticipated educational objectives. These strategies largely relate with the managing of time in the teaching-learning process within classroom. According to Sabelis (2001), the effective utilization of time needs procedures and sound quality planning. This can be achieved by maintaining time logs, setting goals (short term and longterm goals), prioritizing duties, making to-do lists, arranging and organizing one's workstation (Claessens et al., 2007). Time management strategies included a wide range of tasks containing planning, allocating, setting-goals, delegation, analysis of time spent, monitoring, organizing, scheduling, and prioritizing. In addition, other researchers like Richardson and Rothestein, (2008) have highlighted time management strategies consisted of goal-setting, scheduling, prioritizing tasks, selfmonitoring, problem-solving skills, delegating, discussing, and as well as conflict resolution (Morisano, Hirsh, Peterson, Pihl, \& Shore, (2010). Further, according to Morris (2001); Feeny Jonson (2002); Hellsten and Rogers(2009); Hellsten (2012), time management strategies containing: analysis of time, planning, goal-setting, prioritizing, scheduling, organizing, and creating new and improved time-habits are believed indispensable forgood time management. Furthermore, time management records tasks such as constructing lists, listing goals, and using calendars have been recognized by numerous writers as essential for successful time management Claessens et al (2007). 
Time management strategies, according to Khan (2011) included: work-plan (Greene, 2007); school-calendar and activities; to-do list (Claessens et al., 2007); construction of a task list; prioritization of a task list, which can be achieved via many techniques comprises the ABC analysis strategy, Pareto analysis also called 80/20 rule, and Prioritize by Organizing, Streamlining, Economizing and Contributing (POSEC) Technique (Disraeli, 2007); delegating-tasks and assignments (Mathias, 2007), time on task, flexibility, utilization of transition time (Starr, 2007), floating tasks, and procrastination. Procrastination is the thief of time and can be defined as the postponement of activities or tasks to later time despite guessing to be worse off for the delay (Fiore, 2006; Steel, 2007).

The benefits related with efficient time management in instruction are several including: decrease in procrastination; gaining more control, a lesser amount of tension; completing more activities; and enjoying of spare time (Nadinloyi, Hajloo, Garamaleki \& Sadeghi, 2013).

There is substantial research work discussed different features of classroom management. Some researchers have studies the relationship between time management and learner academic achievement. Swart et al (2010) carried out a research to examine the association between time management skills and the learners' academic success. The outcomes revealed no significant association between time management skills and the academic success of the African engineering learners. Further, Miqdadi, Almomani, Masharqa \& Elmousel (2014) performed a research to examine relations between time management and academic achievement of the learners of the Petroleum institute in Abu Dhabi UAE. The upshots revealed that time management is highly correlated with the learners academic achievement performance.

Likewise, Kayode and Ayodele (2015) have investigated the effectiveness of instructor time management on learners' academic performance at secondary school level in Nigeria. Five (500) instructors were chosen from fifty (50) schools via simple random sampling procedures. Data was gathered via a questionnaire of reliability 0.82 and was analyzed via statistical tools. A strong relationship was found between instructors' time management and learners' academic performance. Similarly, a study was conducted by Koohanjani, Khosravi and Fekri (2015) to study the impact of instructor time management skills on achievement motivation and academic performance of secondary school female students in Shiraz. No substantial influence of instructor time management skills was observed on learners' academic performance. However, the studies conducted by of Swart, Lombard \&Henk de Jager (2010) and Koohanjani, Khosravi \&Fekri (2015) showed no statistically significant relationship between time management skills and the academic achievement of students.

But there is limited numbers of researches on the investigation of teachers' classroom time management strategies separately. In this context, a study conducted by Ekanem (2015) aimed at appraising the time management abilities of administrators for skill improvement needs of teachers in secondary schools in Calabar, Nigeria. The population consisted of 28 administrators (principals and vice principals) and 590 teachers of 14 public secondary schools. Twenty eight (28) administrators and 200 teachers were selected through purposive sampling technique. The data analyzed revealed that the school administrators have low knowledge in 
time management strategies. Female administrators had a higher time management abilities in teaching task than male administrators.

\subsection{Statement of the Problem}

This study was planned to explore the teachers' time management strategies employed by classrooms teachers at secondary school level in Khyber Pukhtunkhwah.

\subsection{Objectives of the Study}

Below are the study objectives

- To investigate the teachers Classroom Time Management Strategies (CTMS) at secondary school level.

- To compare male and female teachers classroom time management strategies at secondary school level.

- To compare urban and rural teachers classroom time management strategies at secondary school level.

- To compare science and arts teachers classroom time management strategies at secondary school level.

- To compare public and private teachers classroom time management strategies at secondary school level.

\subsection{Hypothesis of the Study}

To attain the study objectives, the subsequent hypotheses were tested.

- H01.There is no significant difference in the classroom time management strategies adopted by male and female school teachers at secondary level.

- H02.There is no significant difference in the classroom time management strategies adopted by urban and rural school teachers at secondary level.

- H03.There is no significant difference in the classroom time management strategies adopted by science and arts school teachers at secondary level.

- H04.There is no significant difference in the classroom time management strategies adopted by public and private school teachers at secondary level.

\subsection{Significance of the Study}

The chief aim of this research was to explore the approaches of the instructors concerning the instructional procedure in their classroom and what types of classroom time management approaches they were utilizing to keepthe classroom working in the proper direction. In this context, this research is significant for teachers, students, administrators, policy makers, and curriculum planners because they are closely related to classroom management strategies. Since, time management strategies play a vital part the academic achievement of the students and the achievements of the desired educational goals.

\section{Research Methodology and Procedure}

In this survey research design, the researcher has explored the classroom time management strategies utilized by teachers at secondary level. The below processes and techniques were employed to carry out this research.

\subsection{Population and sample of the study}

All teachers at secondary school level of zone two (five district Peshawar, Mardan, Charsada, Nowshera, and Swabi) of Khyber Pukhtunkhwa were considered as the population of this research study. On the whole a sample of 480 teachers was chosen such that from every district 96 teachers were chosen through stratified random sampling technique. Moreover, theses teachers were selected from 80 schools 
(16 schools to each district) carefully. To get the framed objectives, the sample was further divided in to eight (8) strata including public/private, urban/rural, male/female, and science/arts such that the total teachers taken from every division remained the same (240).

\subsection{Research Instrument of the Study}

The researcher prepared a questionnaire on five point Likert scale to measure the performance of secondary school teachers. Further, this questionnaire was consisted of closed ended question and open ended questions as well. The aims of open ended questions were to determine the replies of teachers about their own techniques of classroom time management strategies CTMS. The questionnaire was made valid through judgmental validation. The tool was finalized in the light of the feedback obtained through pilot study (Hundred (100) teachers excluding the sample were piloted). The value of Cronbach's Alpha (0.87) was calculated using SPSS package which is greater than 0.7 , therefore the instrument was reliable.

\subsection{Data Collection and Analysis}

The investigator has personally visited all the sample schools to disseminate the questionnaires amongst the chosen teachers and recollected with cent percent turnouts. The data gathered via questionnaire was tabularized just after coding and scoring. To analyze the data mean, standard deviations, percentages, mean frequency, and t-test were utilized through SPSS Package. The analyzed data was interpreted in to meaningful results of the study. Conclusions and recommendations were drawn on the bases of the outcomes.

\subsubsection{Investigation of teachers' classroom time management strategies (objective} 1)

The teachers responses about time management were sorted out for time management strategies as given in the below figure or table:

$$
\begin{array}{ll}
\text { S/N } & \text { Time management strategies } \\
\mathbf{1} & \text { I follow school calendar and classroom activities } \\
\mathbf{2} & \text { I set goals and work on achieving these goals } \\
\mathbf{3} & \text { I prioritize goals with respect to importance } \\
\mathbf{4} & \text { I make daily scheduleof classroom activities } \\
\mathbf{5} & \text { I use a to-do list to write things down } \\
\mathbf{6} & \text { I prioritize a daily task list to achieve goals } \\
\mathbf{7} & \text { I assign tasks and assignment to students } \\
\mathbf{8} & \text { I avoid lengthy teaching sessions } \\
\mathbf{9} & \text { I set time limit for tasks completion } \\
\mathbf{1 0} & \text { I utilize transition time effectively } \\
\mathbf{1 1} & \text { I improve student attendance } \\
\hline
\end{array}
$$

\section{Results and Discussions}

The responses of the teachers to classroom time management were sorted out for closed ended questions and written down in the tabulated forms as shown in the following tables: 
Table 1: Teachers Willingness Regarding their Classroom Time Management $(\mathrm{n}=\mathbf{4 8 0})$

\begin{tabular}{lll}
\hline \hline Teachers agreement & Frequency & Percent \\
\hline \hline Very Strongly Agree (VSA) & 70 & 15 \\
Strongly Agree (SA) & 90 & 19 \\
Agree (A) & 141 & 29 \\
Disagree (DA) & 66 & 13 \\
Strongly Disagree (SDA) & 60 & 13 \\
Very Strongly Disagree (VSDA) & 53 & 11 \\
Total & 480 & 100 \\
\hline
\end{tabular}

The table 1 shows that about $15 \%$ of the instructors were very strongly agreed, $19 \%$ were strongly agreed, and $29 \%$ were agreed and showed that they were utilizing classroom time management strategies i.e. the majority of the teachers (301) were in favor of classroom time management strategies. However, $13 \%$ were very strongly disagreed, $13 \%$ were strongly disagreed, and $11 \%$ were disagreed i. e. less number of teachers (179) were not agree to utilize CTMS in their routines classroom. Hence, on the whole majority of the teachers showed their willingness in favor of applying CTMS in their routines classroom. The overall picture of teachers' responses about classroom time management is shown in the figure below

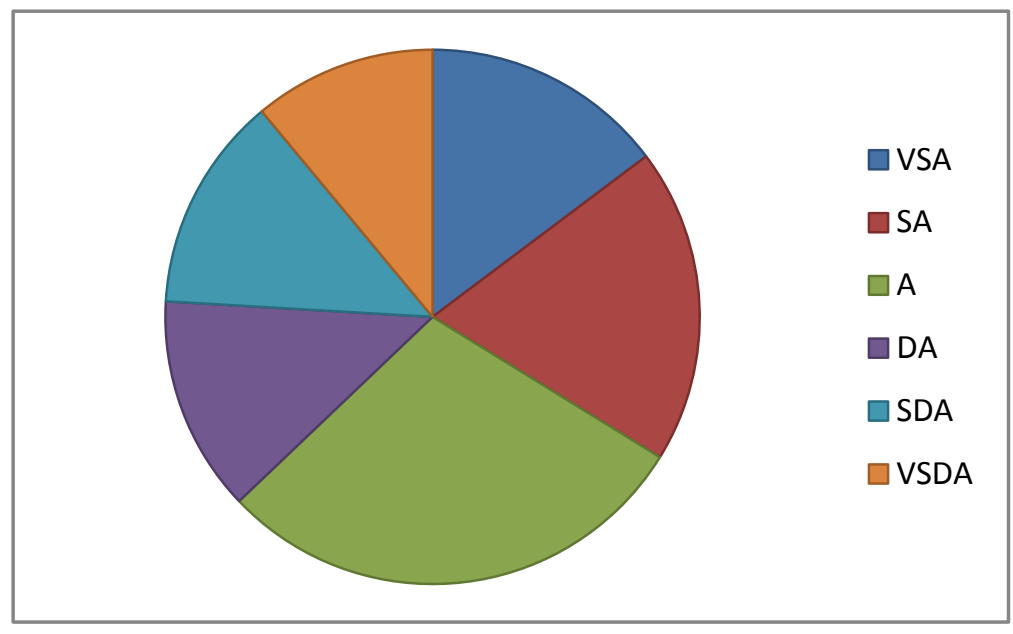

The comparison among various groups of male and female, urban and rural, science and arts, and public and private over CTMS were made through the following tables:

Table 2: Gender differences intime management strategies

\begin{tabular}{llllll}
\hline \hline Gender & N & Mean & S.D & t & Sig. (2-tailed) \\
\hline \hline Male & 240 & 43.32 & 8.62 & & \\
Female & 240 & 39.40 & 10.10 & & 0.000 \\
& & &
\end{tabular}


Table 2 shows that for $\mathrm{p}<0.05$ and $\mathrm{t}>1.96$ the calculated mean scores of male and female teachers for CTMSare(43.32) and (39.40) respectively. As $\mathrm{p}<0.05$, so the disparity among male and female teachers is significant statistically. The hypothesis H01is thereforerejected. Thus, the result shows the supremacy of male teachers over the female teachers in CTMS.These result contrite with the results of the study of Ekanem (2015). Besides, male teachers dominancy over female teachers might be considered due to reasons including: the male instructors higher educations can be a contributor to their superior CTMS; male instructors might attend greater teachers training-workshops during service arranged in the remote locations; female instructors transfer to far-flung zone might severely upset their time management strategies; specific social features like female part in child nurturing and the duties in combined family system can distress their routine; and the absences of female instructor from the school in the academic-year can be a good indicator towards gender disparity in CTMS.

Table 3: Comparison of urban and rural teachers over time management strategies

\begin{tabular}{llllll}
\hline \hline Location & N & Mean & S.D & t & Sig. (2-tailed) \\
\hline \hline Urban & 240 & 44.38 & 8.14 & & \\
Rural & 240 & 38.34 & 9.97 & & \\
\hline
\end{tabular}

Table 3 shows that for $\mathrm{p}<0.05$, and $\mathrm{t}>1.96$, the calculated mean scores of urban and rural teachers for CTMS are (44.38) and (38.34) respectively. The difference between mean scores is substantial statistically. The hypothesis H02is therefore, rejected. Further, the mean scores of urban school teachers are higher than rural teachers. Thus, urban teachers were found superior to rural teachers over CTMS. The supremacy of urban over rural school teachers in CTMS can be linked with many grounds including: the urban teachers may avail more opportunities of trainings and development as compared to rural school teachers; the proficient teachers do not wish to perform in the rural areas due nonexistence of the requisite facilities.

Table 4: Comparison of science and arts teachers over time management strategies

\begin{tabular}{lccccc}
\hline \hline Groups & $\mathbf{N}$ & Mean & S.D & t & Sig. (2-tailed) \\
\hline \hline Science & 240 & 42.69 & 9.35 & & \\
Arts & 240 & 40.03 & 9.65 & & 0.002 \\
\end{tabular}

Table 4 shows that for $\mathrm{p}<0.05$ and $\mathrm{t}>1.96$, the mean calculated scores of science and arts teachers are (42.69) and (40.03) for CTMS. The difference between mean scores is important statistically. The hypothesis H03is therefore, rejected. Thus, science teachers were found superior to arts teachers over CTMS. These results reveal the supremacy of science teachers over the arts teachers. Moreover, this supremacy of science teachers may be due to few causes: the science teachers might be highly 
competent as compared to the arts teachers; the science teachers might be hard worker as compared to arts teachers; the science teachers might be punctual as compared to arts teachers; the science teachers might be well-disciplined because of the nature of their hard subjects (biology, physics, and chemistry).

Table 5: Sector wise comparison of teachers over time management strategies

\begin{tabular}{lccccc}
\hline \hline Groups & N & Mean & S.D & T & Sig.(2-tailed) \\
\hline \hline Public & 240 & 42.90 & 8.42 & & \\
Private & 240 & 39.82 & 10.41 & & 0.000 \\
\hline
\end{tabular}

Table 5 reveals that for $\mathrm{p}<0.05$ and $\mathrm{t}>1.96$, the calculated mean scores ofpublic and private school teachers'for CTMS are (42.90) and (39.82) respectively. Thedifference between mean scores is statistically significant.The hypothesis H04is therefore,completely rejected. Hence, theteachers of public school are found superiortothe private school teachers in time management strategies. Moreover, this superiority of public school teachers may be as a result of few reasons including: the public school teachers are trained and expert andalmost highlyeducated; appoint comparatively less educated teachers to save money might be a factor to be count for low performance in time management specifically in rural private school. On one hand it resolved the shortage of teaching staff but instead it creates low quality upshots.

4.1Analysis of teachers' responses about open ended question about classroom time management strategies

The teachers' responses concerning open ended question of time management strategies were observed. It was noticed that about $25 \%(\mathrm{n}=120)$ teachers "plan their tasks prior to enter the class." $14 \%(n=67)$ teachers were of the opinion that they utilize "a written log or a to-do-list" $13 \%(\mathrm{n}=62)$ teachers "put or fixed deadlines for activities." Moreover, about $10 \%(\mathrm{n}=48)$ teachers "delegate classwork to the pupils", and the same percentage (10\%) of teachers were of the opinion that they employ the techniques of "prioritization of task list." Conversely, 28\% $(n=134)$ of the teachers have given no answer for using the strategies of time management in their routine teaching. In general, $72 \%$ teachers responded that they were employing various kinds of time management strategies in their routine classroom instructions.

\section{Conclusions}

Based on the study findings, it was concluded that majority of the teachers under study were in practice to use classroom time management strategies (CTMS) efficiently, however a fewer teachers did not practice such strategies in their classroom instruction. Further, male teachers were found superior to female school teachers; urban teachers were found superior to rural school teachers; science teachers were found better than arts school teachers in all the features of CTMS; and public school teachers were dominant over private school teacher in CTMS. Furthermore, a huge number of the teachers were using classroom time management strategies in various shapes. They plan tasks prior to enter the class; they make to-do-list; employ the technique of prioritization of task list; they assign classwork to the pupils; and set deadlines to complete activities. 


\subsection{Recommendations}

Keeping in views the results of this research, it was recommended that classroom management related refresher courses may be organized for female teachers to reduce gender disparity in classroom time management strategies; make the teachers of rural school as capable as urban school teachers; make the arts teachers as capable as science teachers. Further, to reduce the gaps between the teachers of public and private schools, the owner of private school may hire competent and experienced staffs in rural area specially and in urban areas normally in order to meet the needful of the teachers. Moreover, it was recommended that change of attitude by the administrators from traditional to innovative techniques of time management in order to improve skills of teachers in the public secondary schools. Further, school principal time management strategies are of outmost importance for developing their attention on instructional management and following school improvement. Furthermore, it is of greater importance to establish a benchmark of the classroom time management skills of the instructor to make a conducive atmosphere of the classrooms towards effective learning. The future investigators are suggested to study the impacts of: instructor's educations on his classroom time management strategies; cultural diversity on instructors' time management strategies; facilities on instructors' classroom time management strategies; leadership styles over instructor's classroom time management strategies; and instructors' background on his classroom time management strategies.

\section{References}

Adamson, B. J., Covic, T. \& Lincoln, M. (2004). Teaching time and organizational management skills to first-year health science students: Does training make a difference? Journal of Further and Higher Education, 28, 261-276.

Afridi, A. K. (2000). School Organization and Classroom Management. Public Art Press, Peshawar. NWFP. (pp.1, 34, 36).

Alay, S., \& Koçak, S. (2003). Relationship between time management and academic achievement of

Allen, D. (2001). Getting Things Done: The Art of Stress-Free Productivity. New York: Viking.

Arends, R. I. (2007). Learning to Teach (7th edn.). (p.173). New York: Random House.

MacCann, C., Fogarty, G. J., \& Roberts, R. D. (2012). Strategies for success in education: Time management is more important for part-time than full-time community college students. Learning and Individual Differences, 22(5), 618-623.

Challam, S. K. (2003). Introduction to Educational Planning and Management. Anmol Publications. Pvt.Ltd, New Delhi, India.(First, edn., p. 123).

Charles, C. M. \& Senter, G.W. (2002). Elementary classroom management ( $3^{\text {rd }}$ edn.). Boston: Allyn\& Bacon.

Claessens, B. J. C., Van Eerde, W. \& Rutte, C. G. (2007). A Review of the Time Management Literature. Personnel Review, 36, 255-274.

Davis, M. A. (2000). Time and the Nursing Home Assistant: Relations Among time Management, Perceived Control Over Time, and Work-Related Outcomes. paper presented at the Academy of Management, Toronto.

Disraeli, B. (2007). Successful Time Management.First things first.Chapter, 5 ( $2^{\text {nd }}$, edn.). Replika Press Pvt Ltd, India. 
Ekanem, E. E. (2015). Time Management Abilities of Administrators for Skill Improvement Needs of Teachers in Secondary Schools in Calabar, Nigeria. Journal of Education and Human Development, 4 (3), 143-149.

Emmer, E.T., Evertson, C.M., \&Worsham, M.E, (2000).Classroom Management for Secondary Teachers, (5th edn.), Boston, Allyn and Bacon.

Evertson, C.M., Emmer, E.T., \&Worsham, M.E. (2003).Classroom Management for Elementary Teachers $\left(6^{\text {th }}\right.$ edn. $)$. Boston: Allyn \& Bacon.

Fazal, S. (2012). The Role of Study Skills in Academic Achievement of Students: A Closer Focus on Gender. Pakistan Journal of Psychological Research, 27 (1), p- 37-51.

Feeney, J. K. (2002). The new elementary teacher's handbook.(2nd ed.). Thousand Oaks, CA: Corwin Press.

Fiore, N. A. (2006). The Now Habit: A Strategic program for overcoming procrastination and enjoying guilt- Free play. New York: Penguin Group.

Forster, M. (2006). Do it tomorrow and other secrets of time Management. Hodder and Stoughton Religious.

Freiberg, H. J. \& Driscoll, A. (2000).Universal Teaching Strategies. ( ${ }^{\text {rd }}$ ed.). Boston: Allyn \& Bacon.

Froyen, L. A., \& Iverson, A. M. (1999). School wide and classroom management:The reflective educator-leader (3rd ed. Pp.128, 181, 221). Upper Saddle River, NJ: Prentice Hall.

Greene, G. (2007). Getting (and staying) organized. In P. Forsyth (Ed), Successful time Management. $(P, 36)\left(2^{\text {nd }}\right.$, edn. p.36) India: Replika Press Pvt Ltd.

Hellsten, L. A. M. (2012). What do we know about time management? A Review of the Literature and a Psychometric Critique of Instruments Assessing Time Management. In Time management.Intech.

Hellsten, L.M, \& Rogers, W. T. (2009).Development and preliminary validation of the Time Management for Exercise Scale. Measurement in Physical Education and Exercise Science, 13, 13-33

Iverson, A. M. (2003). Building Competence in Classroom Management and Discipline (4th edn.). (p.4). Upper Saddle River, N.J.: Merrill.

Kayode, G. M. \& Ayodele, J. B. (2015). Impacts of Teachers' Time Management on Secondary School Students' Academic Performance in Ekiti State, Nigeria. International Journal of Secondary Education, 3(1): 1-7. http://www.sciencepublishinggroup.com/j/ijsedu

Khan, K. (2011). An Investigation of Teacher Classroom Management Strategies at Secondary School Level, (Pp.1-140). M. Phil Thesis Unpublished, Education Department, Hazara University, Mansehra. Khyber Pakhtunkhwah, Pakistan.

Khan, K., Khan, M. S., \& Majoka, M. I. (2011).Gender Difference in Classroom Management Strategies at Secondary Level. Interdisciplinary Journal of Contemporary Research in Business, 3(3), 580-588.

Koohanjani, S. T., Khosravi, S. \& Fekri, C. (2015).Efficacy time management skills training on academic performance of high school female students in Shiraz.Indian Journal of Fundamental and Applied Life Sciences, 5 (S3), 1048-1054.An Open Access, Online International Journal Available at www.cibtech.org/sp.ed/jls/2015/03/jls.htm 
Larrivee, B. (2005). Authentic classroom management: Creating a learning community and building a reflective practice. Boston: Pearson.

Liu, O. L., Rijmen, F., MacCann, C., \& Roberts, R. (2009).The assessment of time management in middle-school students.Personality and Individual Differences, 47, 174-179.

Macan, T. H., Shahani, C., Dipboye, R. L. \& Phillips, A. P. (2000). College student's time management: Correlations with academic performance and stress. Journal of Educational Psychology, 82 (4), 760-768.

Mathias, C.M. (2007). Working With Other People. In P. Forsyth (Eds.).Successful Time Management (pp.122-128), (2nd, edn.). India: Replika Press, Pvt Ltd.

Miqdadi, F. Z., Momani, A. F., Masharqa,S. M. T. \& Elmousel, N.M. (2014).The relationship between time management and the academic performance of students from the petroleum institute in Abu Dhabi, the UAE. 1-5, Paper read in ASEE 2014 Zone I Conference, April 3-5, 2014, University of Bridgeport, Bridgpeort, CT, USA.

Morgenstern, J. (2004). Time Management from the Inside Out: The Foolproof System for Taking Control of Your Schedule--and Your Life $\left(2^{\text {nd }}\right.$, edn.). New York: Henry Holt/Owl Books.

Morisano, D., Hirsh, J. B., Peterson, J. B., Pihl, R. O., \& Shore, B. M. (2010). Setting, elaborating, and reflecting on personal goals improves academic performance. Journal of Applied Psychology, 95, 255-264.

Morris, T. (2001). 101 time smart solutions for teachers. Winnipeg, MB: Portage \& Main Press.

Nadinloyi, K. B., Hajloo, N., Garamaleki, N. S., \&Sadeghi, H. (2013).The study efficacy of time management training on increase academic time management of students. Procedia-Social and Behavioral Sciences, 84, 134138.

Parkay, F. W. \& Hass, C. G. (2000). Curriculum planning: A contemporary approach $\left(7^{\text {th }}\right.$, edn.). Boston: Allyn\& Bacon.

Raymond, L. (2008). Achieving objectives made easy; Practical goal setting tools \& proven time management techniques. Maarheeze: Cranendonck Coaching.

Richardson, K. M., \& Rothstein, H. R. (2008). Effects of occupational stress management intervention programs: A meta-analysis. Journal of Occupational Health Psychology, 13, 69-93.

Sabelis, I. (2001). Time Management. Time and Society, 10(2-3), 387-400.

Samson, D. \& Daft, R.L. (2003).Management.Pacific Rim Edition, Nelson Australia Pty Limited, (Fifth Ed, pp.9-10).

Santrock, J. W. (2004). Educational Psychology.(2 ${ }^{\text {nd }}$, edn.). (pp. 459-460). McGrawHill, inc., 1221. New York, America.

Shahid, S.M. (2005). Educational Management and Supervision. Z.A. Printer Lahore, pp. 91-95. (First Ed, 2004-2005).

Starr, L. (2007). Transition Time. Retrieved February 15, 2009 from www.education worldwide.com

Steel, P. (2007). The Nature of procrastination: A Meta-Analytic and Theoretical Review of Quintessential Self-Regulatory Failure.

Strongman, K. T., \& Burt, C. D. (2000). Taking breaks from work: An exploratory inquiry. The Journal of psychology, 134(3), 229-242. 
Swart, A. J., Lombard, K. \& Jager, H. De. (2010). Exploring the Relationship Between Time Management Skills and the Academic Achievement of African Engineering Students - A Case Study. European Journal of Engineering Education, 35 (1), 79-89.

Ugwulashi, C. S. (2013).Time Management: Essential Tool for Teaching and Learning Improvement in Challenging Resource Period in Nigeria. Educational Research International, 1(2), 61-68. 